\title{
Pelatihan Pembuatan Media Pembelajaran Pendidikan Agama Islam
}

\author{
Rosmiati \\ rosmiati.rosmiati@umi.ac.id
}

Dosen Fakultas Agama Islam Universitas Muslim Indonesia Makassar

\begin{abstract}
Abstrak
Tujuan pelaksanaan program Pkmd bagi Masyarakat ini adalah: (a) Membentuk kelompokkelompok kerja guru (KKG), (b) meningkatkan pengetahuan dan keterampilan para guru tentang pembuatan media pembelajaran Pendidikan Agama Islam dengan pendekatan IPTEK terapan, (c) melatih pembuatan media pembelajaran Pendidikan Agama Islam dengan pendekatan IPTEK terapan, (d) melatih dan mendampingi guru bagaimana cara penggunaan media pembelajaran dalam pembelajaran Pendidikan Agama Islam di kelas. Metode pelaksanaan kegiatan menggadopsi pola pelaksanaan penelitian tindakan meliputi empat tahap, yaitu: perencanaan programpembelajaran , pelaksanaan program pembelajaran , observasi dan evaluasi, dan refleksi. Hasil pelaksanaan program adalah (a) terbentuk 2 kelompok kerja guru dengan masing-masing anggota sebanyak 6 orang dengan menbentuk kelompok sampai 2 kelompok kerja guru yang dibentuk berdasarkan rumpun ilmu; (b) adanya peningkatan pengetahuan dan keterampilan para guru tentang pembuatan media pembelajaran Pendidikan Agama Islam dengan pendekatan IPTEK terapan, dari kategori "cukup" menjadi "baik"; (c) dihasilkan sebanyak 2 set media (alat peraga) Pendidikan Agama Islam untuk siswa Madrasah Tsanawiah DDI Padanglampe Marrang Kabupaten Pangkep , meliputi materi: Udhu, Shalat, dengan kualitas 'baik'. (d) kemampuan guru dalam menggunakan media pembelajaran dalam pembelajaran Pendidikan Agama Islam di kelas berkualitas "baik".
\end{abstract}

Keywords: Media, Pembelajaran, Pendidikan Agama Islam

\section{Pendahuluan}

\subsection{Analisis Situasi}

Lokasi Marang Kabupaten Pangkep, sekitar 10 km dari Kota Pangkep, Madrasah Tsanawiayah DDI Padanglampe. Yang memiliki guru 24 orang. Lokasi sekolah-sekolah tersebut, terletak di daerah pedesaan sehingga kegiatan KKG di bidang pendidikan yang dilakukan kota kecamatan. Lokasi-lokasi sekolah yang sebagian besar terletak pada daerah yang agak terpencil mengakibatkan para guru jarang terlibat dalam kegiatan-kegiatan ilmiah yang dilakukan oleh Perguruan Tinggi. Sebagai dampaknya pengetahuan dan pemahaman para guru di wilayah ini masih kurang terkait dengan desain pembelajaran ataupun inovasi-inovasi kegiatan pembelajaran lainnya.

Berdasarkan hasil wawancara dengan beberapa guru dan kepala sekolah di Madrasah Tsanwiayah DDI Padanglampe kabupaten Pangkep. Madarasah Tsanawiyah DDI Padanglampe kabupaten pangkep yang dilakukan pada bulan juni 2018, diperoleh informasi 
bahwa, pembelajaran Pendidikan Agama Islam yang dilaksanakan selama ini sangat jarang menggunakan media, khususnya yang berupa alat peraga ataupun media-media inovatif lainnya. Siswa belajar Pendidikan Agama Islam lebih banyak melalui penjelasan secara langsung oleh guru yang didominasi dengan pemberian ceramah. Hal ini terjadi sebagai akibat dari sarana dan prasarana khususnya terkait dengan media pembelajaran yang tersedia sangat kurang, khususnya tentang media dan pemahaman serta keterampilan guru untuk merancang media pembelajaran Pendidikan Agama Islam juga sangat kurang. Sebagai akibatnya siswa belajar Pendidikan Agama Islam dengan cara-cara yang kurang bermakna. Siswa cenderung menghafal konsep atau prosedur Pendidikan Agama Islam tertentu dan belajar Pendidikan Agama Islam lebih banyak secara mekanistik. Hal ini berdampak pada rendahnya prestasi belajar Pendidikan Agama Islam yang dicapai siswa dan pembelajaran Pendidikan Agama Islam berlangsung dengan membosankan. Sebagai gambaran keberadaan sekolah dan guru Madrasah Tsanawiyah DDI Padanglampe Kabupaten Pangkep

Mempertimbangkan jumlah guru yang cukup, dengan pemahaman yang masih kurang dalam desain pembelajaran, khususnya dalam merancang media pembelajaran yang inovatif, maka para guru dan kepala sekolah bersama dengan pelaksana IbM ini memandang perlu untuk mengadakan kegiatan KKG-PKM yang melibatkan para guru di daerah ini, bahkan Para kepala sekolah sangat berharap kegiatan ini besa berlangsung segera. Hal ini karena mereka memangdang pada guru di daearah ini sangat memerlukan penyegaran terkait dengan media pembelajaran, agar dapat menegmbangkan kemampuan profesionalisme mereka yang bermuara pada peningkatan kualitas hasil belajar pendidikan Agama Islam (rumpun Pendidikan Agama Islam) Tabel 1. Madrasah Tsanawiyah DDI Padanglampe Kabupaten Pangkep.

\begin{tabular}{|l|l|l|l|}
\hline $\begin{array}{l}\text { N } \\
\text { O }\end{array}$ & Jenis kelamin & Jumlah & Total \\
\hline 1 & Laki-laki & 20 & 20 \\
\hline 2 & Perempuan & 4 & 4 \\
\hline 3 & & Total & 24 \\
\hline
\end{tabular}

Kegiatan PKM ini mula-mula dilakukan pada 1 Madrsah Tsanawiyah DDI Padanglampe Kabupaten Pangkep sebagai mitra. Para guru yang dilibatkan 13 guru sekolah ini diminta untuk mendiseminasikan kegiatan ini pada gugus sekolahnya masing-masing di bawah bimbingan tim pelaksana kegiatan PKM. Kegiatan ini dimaksudkan untuk memotivasi para guru dan siswa di Madarasah Tsanawiyah DDI Padangalampe kabupaten Pangkep tersebut agar mau melaksanakan kegiatan belajar dan mengajar secara lebih efektif dan inovatif. Di samping itu, agar para guru dalam mengajar mau melakukan inovasi-inovasi sebagai bagian dari tugas profesionalismenya. Media pembelajaran Pendidikan Agama Islam yang dikembangkan, diharapkan mampu memfasilitasi siswa untuk belajar Pendidikan Agama Islam dengan lebih mudah sehingga proses dan hasil belajar dapat dicapai dengan lebih berkualitas. 


\subsection{Permasalahan Mitra}

(1) Sebagai mitra dalam pelaksanaan PKM ini adalah Madarsah Tsanawiyah DDI Padanglampe kecamatang Marrang Kabupaten Pangkep.

Yaitu Madrasah Tsanawiyah DDI Padanglampe Kabupaten Pangkep. Berdasarkan analisis situasi dapat teridentifikasi beberapa permasalahan yang dihadapai oleh mitra, yaitu:

(a) Rata-rata hasil belajar Pendidikan Agama Islam siswa berada di bawah kriteria ketuntasan minimal (KKM) yang ditetapkan oleh sekolah, yaitu 7,0 untuk mata pelajaran rumpun Pendidikan Agama Islam.

(b) Siswa kesulitan belajar Pendidikan Agama Islam karena konsep-konsep Pendidikan Agama Islam yang dipelajari cenderung dihafalkan tanpa dipahami terlebih dahulu, sehingga kalau diberikan soal lain dari contoh yang diberikan oleh gurunya, siswa kesulitan untuk menjawabnya.

(c) Pelaksanaan pembelajaran Pendidikan Agama Islam, dirasakan kurang menarik bagi siswa dan cenderung membosankan, karena dipenuhi oleh latihan-latihan, sehingga siswa sangat jarang mendapatkan kesempatan untuk melakukan kegiatan eksplorasi/penemuan yang menantang dan memotivasi semangat belajarnya.

(d) Motivasi para guru untuk melaksanakan inovasi pelaksanaan pembelajaran sangat rendah, karena mereka jarang mengikuti kegiatan-kegiatan ilmiah terkait.

(e) Pengetahuan para guru dalam merancang dan menggunakan media pembelajaran Pendidikan Agama Islam yang inovatif sangat kurang. Selain itu, dari pihak sekolah juga tidak menyediakan media ataupun alat-alat peraga Pendidikan Agama Islam (rumpun pendidikan Agama Islam) yang dapat digunakan oleh guru dalam melaksanakan pembelajaran. Hal ini berdampak pada pelaksanaan pembelajaran Pendidikan Agama Islam berlangsung dengan cara yang kurang bermakna dan didominasi oleh ceramah langsung oleh guru. Adapun alat praga yang ada sangat terbatas disebabkan karna kemampuan ekonomi.

\subsection{Target}

\section{Target dan Luaran}

Target yang ingin dicapai melalui kegiatan PKM ini adalah sebagai berikut.

1) Teridentifikasinya konsep-konsep Pendidikan Agama Islam Madrasah Tsanawiyah DDI padanglampe Kabupaten Pangkep yang esensial yang bisa diajarkan dengan lebih mudah kalau menggunakan media pembelajaran Pendidikan Agama Islam inovatif. Sebagai kriterianya adalah minimal 50\% materi Pendidikan Agama Islam Madrasah Tsanawiah DDI Padanglampe Kabupaten Pangkep dapat dibuatkan media/alat peraga yang inovatif dan power poin.

2) Adanya kelompok-kelompok kerja Guru Pendidikan Agama Islam (KKG) dengan kemampuan IPTEK terapan dalam memproduksi media pembelajaran Pendidikan Agama Islam. Sebagai kriterianya adalah minimal $60 \%$ dari guru mitra memiliki pengetahuan yang 'cukup' dalam memproduksi media pembelajaran Pendidikan Agama Islam yang inovatif.

3) Adanya produk media pembelajaran Pendidikan Agama Islam yang inovatif beserta cara pembelajaran dan dilengkapi dengan petunjuk penggunaannya, dengan target produksi 
media pembelajaran minimal 2 alat peraga yaitu tata cara shalat dan tata cara udhu Pendidikan Agama Islam inovatif.

\subsection{Luaran}

Luaran yang diharapkan melalui kegiatan PKM ini adalah:

1).Media/alat peraga Pendidikan Agama Islam Madrasah Tsanawiyah DDI padanglampe yang inovatif, beserta buku petunjuk penggunaannya.

2)Kemampuan guru yang cukup dalam memproduksi dan mengimplementasikan media pembelajaran Pendidikan Agama Islam yang inovatif.

\section{Metode Pelaksanaan}

\subsection{Solusi yang ditawarkan}

Berdasarkan permasalahan yang dihadapi oleh mitra seperti terungkap dalam bab sebelumnya, beberapa alternatif solusi yang dapat ditawarkan adalah sebagai berikut.

(1) Pembentukan/Pembinaan kelompok kerja guru (KKG) Pendidikan Agama Islam, yang diharapkan dapat mengatasi permasalahan pembelajaran Pendidikan Agama Islam dan mampu menjadi wahana dalam memfasilitasi pengembangan profesionalisme para guru Madrasah Tsanawiyah DDI Padanglampe Kabupaten Pangkep di pedesaan.

(2) Menambah pengetahuan para guru tentang penerapan IPTEK untuk merancang media pembelajaran Pendidikan Agama Islam yang inovatif dan memiliki kemampuan untuk mengimplementasikannya dalam kegiatan pembelajaran.

(3) Menambah wawasan para guru terkait dengan pengelolaan KKG secara efektif dan optimal. Berikut dijelaskan teknologi yang ditawarkan dalam upaya produksi media pembelajaran Pendidikan Agama Islam Madrasah Tsanawiayah DDI Padanglampe Kabupaten Pangkep yang inovatif dan

teknis penggunaannya. desain/perancangan media pembelajaran Pendidikan Agama Islam inovatif dapat digambarkan sebagai berikut.

Sebagai contoh, pembuatan media pembelajaran Pendidikan Agama Islam 'Tata cara pelaksanaan wudhu' Tata cara shalat

1) Model media (alat peraga)

a. Tata Cara wudhu

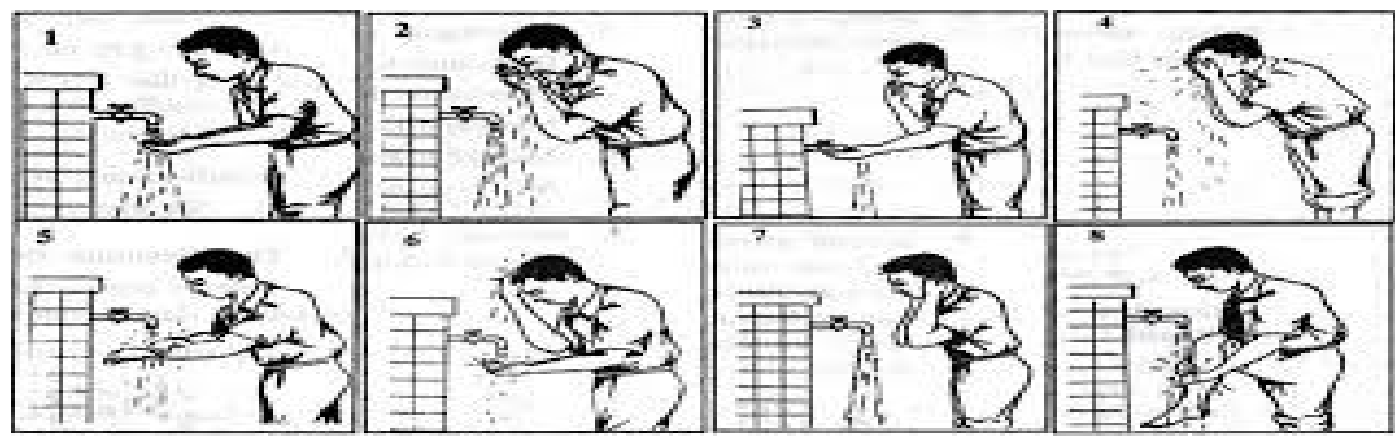




\section{Realisasai Kegiatan}

1.Tim Pelaksana.

\begin{tabular}{|l|l|l|l|l|}
\hline No & Tim Pelaksana & $\begin{array}{l}\text { Jabatan } \\
\text { posisi }\end{array}$ & $\begin{array}{l}\text { Bidang } \\
\text { Keahlian }\end{array}$ & Tugas Dalam Kegiatan \\
\hline 1. & Dr. Hj. Rosmiati, M.Pd & $\begin{array}{l}\text { Ketua } \\
\text { TIM }\end{array}$ & $\begin{array}{l}\text { Imu } \\
\text { Pendidikan }\end{array}$ & $\begin{array}{l}\text { Melatih guru dalam } \\
\text { pembutan } \\
\text { pembelajaran. }\end{array}$ \\
\hline 2 & $\begin{array}{l}\text { Drs.H.Abd Rauf } \\
\text { Assagaf, M.Pd }\end{array}$ & $\begin{array}{l}\text { Anggota } \\
\text { TIM }\end{array}$ & $\begin{array}{l}\text { Manajem } \\
\text { Pendidikan }\end{array}$ & $\begin{array}{l}\text { Membantu Ketua Tim } \\
\text { dalam melaksanakan } \\
\text { Penelitian } \\
\text { Mendampingi guru } \\
\text { memberikan motivasi }\end{array}$ \\
\hline 3 & Muh Aras & $\begin{array}{l}\text { Anggota } \\
\text { TIMin pengabdian. }\end{array}$ \\
\hline
\end{tabular}

\section{Bentuk Kegiatan}

Bentuk kegiatan ini berupa pelatihan pembuatan media Pembelajaran Pendidikan Agama Islam di Madrasah tsanawiyah DDI padanglampe Kabupaten Pangkep. Secara langsung dilaksanakan tim pengabdi dan anggotanya, mahasiswa dan peserta penlatihan adalah guru-guru yang terdiri dari 13 orang peserta dari jumlah guru 24 orang. Sembilang diantaranya adalah guru rumpun pendidikan Agama Islam dan 4adalah rumpun mata pelajaran umum.

a. waktu Kegiatan

Kegiatan ini mulai dilaksanakan 18 september, tanggal 2 nopember 2019 yang belokasi di Madrasah Tsanawiyah DDI Padanglampe Kabupaten Pangkep.

.b. Tempat Pelaksanaan

Kegiatan ini diselenggarakan secara langsung oleh tim peneliti sebagai pelaksana pengabdian masyarakat dalam pelatiahan media pembelajaran Pendidikan Agama Islam di Madrsah Tsanawiah DDI padanglampe Kabupaten Panggkep yang menjadi mitra dengan sejumlah guru 24 orang namun guru rumpun Pendidikan Agama Islam sebanyak 9 Orang. Namun Jumlah peserta sebanyak 13 Orang, 9 orang guru rumpun Pendidikan Agama Islam dan 4 Rumpun mata pelajaran umum.

Kegiatan pelaksanaan dilaksanakan pelatihan dilaksanaka satu kali namun kunjungan ke sekolah sebnyak 3 kali dikunjungi Madarsah Tsanawiyah DDI Padangolampe Kanupaten Pangkep.

5. Tinjauan Hasil yang dicapai

\section{Peserta Partisipasi masaarakat sasaran.}

Kegiatan-kegiatan yang dilakukan pada tahap perencanaan adalah sebagai berikut.

(1) Pembentukan dan pembekalan kelompok kerja guru (KKG) Pendidikan Agama Islam Pelaksanaan tahap ini didahului dengan mengundang tim pelaksana untuk mengadakan pertemuan persiapan pelaksanaan dengan melibatkan LPMD UMI Makassar. Kegiatan ini dilakukan pada bulan April sampai dengan bulan Mei 2018. Tim pelaksana diberikan 
pembekalan mengenai maksud, tujuan, rancangan mekanisme program KKG, dan beberapa hal teknis berkaitan dengan metode/teknik pelaksanaan.

\section{(2) Sosialisasi program KKG pada dua sekolah mitra (khalayak sasaran)}

Sosialisasi dilakukan pada bulan Juni 2018 dalam bentuk rapat koordinasi dengan mengundang semua guru pada sekolah mitra yaitu Madrasah Tsanawiah DDI Padanglamp , Kepala Sekolah adalah alumni Fakultas agama Islam prodi Pendidikan Agama Islam, dan Kepala UPTD Dinas Pendidikan Pemuda Dan Olah Raga Kecamatan Marang , berkenaan dengan program yang dilaksanakan. Kegiatan sosialisasi dilakukan oleh Tim Pelaksana didampingi oleh Tim pengebdi UMI Makassar.

\section{(3) Penyusunan program pelatihan}

Berdasarkan hasil identifikasi, hasil analisis permasalahan yang ada, hasil analisis kebutuhan, dan hasil analisis potensi sekolah, selanjutnya disusun program pelatihan. Pelaksanaan pelatihan dilakukan selama 1 hari tatap muka, dengan mengundang 13 orang guru Madrasah Tasanawiayah DDI Padanglampe Kabupaten Pangkep yang ada di Kecamatan Marrang. Pelatihan yang diberikan berupa penyusunan RPP berdasarkan kurikulum 2013 dan prosedur pembuatan media pembelajaran Pendidikan Agama Islam serta cara mengimplementasikannya dalam kegiatan pembelajaran.

\section{1 Tinjauan Hasil yang di Capai .}

Tindakan dalam kegiatan ini berupa implementasi Program. Kegiatan-kegiatan yang dilakukan dalam implementasi program adalah sebagai berikut. (a) Pembentukan kelompok-kelompok kerja guru, kegiatan ini dilaksanakan pada bulan 2 Nopember 2019. Berdasarkan distribusi lokasi sekolah, dibentuk 2 kelompok kerja guru dengan masingmasing anggota sebanyak 3 sampai 7 orang. (b) Meningkatkan pengetahuan dan keterampilan para guru tentang pembuatan media pembelajaran Pendidikan Agama Islam dengan pendekatan IPTEK terapan. Kegiatan ini dilakukan melalui pemberian pelatihan tentang pembuatan media pembelajaran Pendidikan Agama Islam dan penyusunan buku petunjuk penggunaannya, serta penyusunan RPP. Pemberian teori dilakukan dalam satu hari kegiatan pelaksanaan dilakukan pada tanggal 21 September 2018 bertempat di Madrasah Tasanawiyah DDI Padanglampe, dilanjutkan dengan kegiatan penyempurnaan pada masing-masing $\mathrm{KKG}$, dibawah bimbingan tim pelaksana PKM. (c) mendemonstrasikan teknologi pembuatan media pembelajaran Pendidikan Agama Islam dengan pendekatan IPTEKS terapan, dilakukan dalam kegiatan pelatihan. (d) Pembinaan dan pelatihan teknologi pembuatan media pembelajaran Pendidikan Agama Islam, dan (e) pelatihan cara penggunaan media pembelajaran dalam pembelajaran Pendidikan Agama Islam di kelas. Kegiatan ini dilakukan sampai awal bulan Nopember, luaran kegiatan berupa 2 set media pembelajaran Pendidikan Agama Islam inovatif beserta buku petunjuk penggunaannya (lampiran 2).

\subsection{Evaluasi Kegiatan}

Evaluasi dilakukan terhadap proses pembuatan dan penerapan media pembelajaran Pendidikan Agama Islam di kelas oleh para guru mitra. Evaluasi dilakukan terhadap kuantitas dan kualitas produk yang dihasilkan. Produk yang dihasilkan dalam kegiatan ini adalah media pembelajaran Pendidikan Agama Islam inovatif. Kuantitasnya dilihat dari banyaknya alat peraga/media yang dihasilkan oleh para guru, sedangkan 
kualitasnya terlihat dari meningkatnya hasil belajar Pendidikan Agama Islam siswa dari sebelumnya. Instrumen evaluasi adalah lembar penilaian berupa alat penilaian kemampuan mengajar guru (APKG) termasuk rencana pelaksanaan pembelajaran (RPP) yang dibuat oleh guru. Penilaian terhadap kualitas RPP dan kemampuan mengajar guru dilakukan menggunakan penilaian.

Beberapa hal yang diobservasi adalah kendala-kendala, kekurangan-kekurangan, dan kelemahan-kelemahan yang muncul dalam proses pembelajaran berbantuan media inovatif di kelas. Kendala yang dihadapi sebagian besar guru dalam pelaksanaan pembelajaran Pendidikan Agama Islam berbantuan media inovatif adalah penguasaan terhadap materi Pendidikan Agama Islam masih kurang. Media yang digunakan masih secara klasikal, penggunaannya belum bisa diliat langsung oleh siswa. Namun melalui penggunaan media yang dipandu oleh guru, siswa telah berhasil belajar dengan cara yang lebih bermakna karena mereka dipandu untuk bisa menemukan konsep dari simulasi media tersebut.

Evaluasi dilakukan terhadap kemampuan guru dalam mengimplementasikan media pembelajaran Pendidikan Agama Islam dalam kegiatan pembelajaran di kelas. Instrumen yang digunakan adalah alat penilaian kemampuan guru (APKG) yang diadopsi dari APKG sertifikasi guru Di Padanglampe tahun 2018. Evaluasi dilakukan pada 2 orang guru yang dipilih, Madrasah Tsanawiyah DDI Padanglampe Kabupaten Pangkep. Hasil evaluasi adalah rata-rata kemampuan mengajar guru menggunakan media pembelajaran Pendidikan Agama Islam yang telah dikembangkan berkualitas "baik" dan RPP yang disusun guru, berkualitas "baik". Rata-rata hasil belajar Pendidikan Agama Islam siswa mengalami peningkatan dari 6,2 sebelum pelaksanaan pembelajaran berbantuan media menjadi 7,4 setelah pelaksanaan pembelajaran berbantuan media.

\subsection{Pembahasan}

Kegiatan Pkmd yang dilaksanakan pada guru-guru Madrasah Tsanawiyah DDI Padanglampe telah berlangsung dengan baik. Hal ini terlihat dari animo guru untuk mengikuti kegiatan pelatihan sangat tinggi, terbukti dengan kehadiran para guru untuk mengikuti kegiatan mencapai $78 \%$. Hal ini mengindikasikan bahwa para guru menyambut positif kegiatan yang telah dilakukan. Sesuai dengan harapan para sekolah, mereka sangat mengharapkan adanya kegitan-kegiatan yang sifatnya memberi penyegaran bagi para guru di daerah ini, baik terkait dengan pendalaman materi bidang studi ataupun terkait dengan metode mengajar, mengingat hampir $60 \%$ dari para guru sudah berumur di atas 40 tahun.

Kepala sekolah, dan pengawas, menyambut antusias berharap dilakukan kegiatan secara berkesinambungan dan disarankan untuk mengembangkan media yang disusun untuk materi-materi yang lain. juga berharap agar ada pembinaan dari perguruan tinggi di daerah ini. guru sangat antusias dalam mempraktekkan alat-alat peraga (media) yang telah disusun dalam kegiatan peer teaching. Banyak masukan yang diberikan, baik oleh para guru ataupun oleh tim pelaksana Pkmd terkait dengan pelaksanaan pembelajaran berbantuan media inovatif. Masukan yang diberikan oleh tim pelaksana Pkmd lebih banyak tentang pendalaman materi bidang studi terkait dengan media yang dikembangkan, misalnya materi tentang pengertian simetri putar dan cara mengajarkannya menggunakan media. Sebanyak tujuh alat peraga yang sempat disimulasikan dan kemampuan mereka berkualitas 'cukup' dan 'baik'. Dari 13 orang guru 
yang mengikuti pelatihan dipilih 2 orang yang didampingi untuk melaksanakan pembelajaran Pendidikan Agama Islam berbantuan media inovatif pada kelas dan sekolah di masing-masing.

Melalui kegiatan pendampingan, pelaksanaan pembelajaran berbantuan media inovatif dapat berlangsung dengan baik. RPP yang disusun disesuaikan dengan kurikulum 2013, dengan menyusun RPP tematik. RPP yang disusun berkualitas 'baik'. Kemampuan guru yang dinilai menggunakan APKG, berkualitas 'baik'. Rata-rata hasil belajar Pendidikan Agama Islam siswa mengalami peningkatan dari sebelum pelaksanaan pembelajaran berbantuan media dengan setelah pelaksanaan pembelajaran berbantuan media.

Kendala-kendala yang dihadapi dalam pelaksanaan KKG ini adalah masalah waktu pelaksanaan sering terganggu dengan adanya hari-hari libur keagamaan dan kegiatankegiatan yang lain. Di samping itu masalah yang cukup mengganggu adalah keterlambatan pencairan dana, sehingga waktu pelaksanaan kegiatan menjadi mundur, tidak bisa berlangsung sesuai dengan rencana. Namun, semua kendala dan masalah yang muncul telah dicarikan solusinya, yaitu dengan melaksanakan kegiatan pelatihan pada hari sabtu dan lebih banyak kerja dalam kelompok kerja guru (KKG). Dengan demikian kegiatan KKG ini telah berlangsung dengan baik.

4.6. Permasalahan dan Hambatan.

a. Masih ada peserta tidak konsisten dengan jadal yang telah di sepakati sebelum pelatihan di laksanakan. Disebabkan dengan permasalahn karena studi lanjut

b. Wilayah pengadian ang sangat jauh dan terlambat karna kondisi taransportasi.

c. Kuarangnya perangkat pendukung yang diperlukan dalam kegiatan karna dia berada di daera terpencil.

d. Kelompok Kerja guru tdk perna melaksanakan kegiatan.

\section{Kesimpulan dan Saran}

\subsection{Kesimpulan}

Hasil yang dicapai melalui kegiatan KKG ini adalah sebagai berikut.

1. Adanya peningkatan pengetahuan dan keterampilan para guru tentang pembuatan media pembelajaran Pendidikan Agama Islam dengan pendekatan IPTEK terapan, dari kategori "cukup" menjadi "baik"

2. Dihasilkan sebanyak 2 set media (alat peraga) Pendidikan Agama Islam untuk siswa Madrsah Tsanwiyah DDI Padanglampe Kabupaten Pangkep, Meliputi materi: tata cara udhu dan tata cara shalat, dengan kualitas baik.

3. Rata-rata kemampuan mengajar guru menggunakan media pembelajaran Pendidikan Agama Islam yang telah dikembangkan, berkualitas "baik".

4. RPP yang disusun guru, berkualitas "baik".

6. Rata-rata hasil belajar Pendidikan Agama Islam siswa mengalami peningkatan dari 6,2 sebelum pelaksanaan pembelajaran berbantuan media menjadi 7,4 setelah pelaksanaan pembelajaran memakai media. 


\subsection{Saran.}

Berdasarkan hasil yang diproleh dalam kegiatan ini beberapa saran yang bisa di sampaikan sebagai berikut.

1. Para guru Madrasah Tsanawiah DDI Padanglampe Kabupaten Pangkep agar sengantiasa berupaya secara terus-menerus mengembangkan kemampuan profesionalismenya mealui kegiatan (KKG), melalui KKG masalah yang dihadapi oleh guru dapat dicarikan solusinya secara bersama-sama.

2. Media pembelajaran yang telah dihasilakan agar dilaksanakan secara berkesinambungan dan agar dilakukan pengembangan media pembelajaran terkait dengan materi yang lain, baik bidang studi pendidikan agama islam maupun mata pelajaran lainnya, mengingat tahap perkembangan berfikir anak Madrasah Tsanawiyah DDI Padanglampe Kabupaten Pangkep masih berada pada tahap oprasi konkrit.

3. Bagi yang berminat, agar melakukan kegiatan lanjutan berupa produksi media pembelajaran untuk jenjang sekolah yang lebih tinggi, misalnya mengembangkan media pembelajaran berbasis ICT.

\section{Daftar Pustaka}

Dick, W., Carey, L., \& Carey, J. O. 2001. The Systematic Design Of Instruction. USA: Addison-Wesley Educational Publisher Inc.

Dirjen Dikti. 2005. Pedoman Umum: Pengembangan Sistem Asesmen Berbasis Kompetensi. Depdiknas: Jakarta.

Gagne, R. M. 1985. The conditions of learning and theory of instruction. New York: CBS College Publishing.

Heinich, R., Molenda, M., Rusell, J. D., \& Smaldino, S.E. 2002. Instructinal media and technology for larning, $7^{\text {th }}$ edition. New Jersey: Prentice Hall, Inc.

Januszewski, A., Molenda, M. 2008. Educational Technology. New York: Lawrence Erlbaum Associates.

Martha, E. R. D., Rosalind, H. \& Ted, W. P. 1993. Theory and Research in Social Education. Vol. 4. Washington DC: NCSS.

Parwati, N.N. \& Sadra, I. W. 2003. Pelatihan Pembuatan Alat Peraga Pendidikan Agama Islam Bagi Guru-guru SD. Laporan KKG. Tidak diterbitkan. Singaraja: IKIP Negeri Singaraja.

Parwati, N.N., Mariawan, I. M., \& Suarsana, I. M. 2007. Peningkatan Profesionalisme Guru Pendidikan Agama Islam Melalui Pelatihan Implementasi Model-model Pembelajaran Berbantuan .Alat Peraga Bagi Guru-Guru Sekolah Dasar No 3 Mengesta.Laporan KKG. Tidak diterbitkan. Singaraja

Parwati, N.N. \& Mariawan, I. M. 2008. Pelatihan Penelitian Tindakan Kelas untuk Guruguru MTS DDI PADANGLAMPEdi Kabupaten Tabanan. Laporan KKG. Tidak diterbitkan. Singaraja 
Parwati, N.N. \& I P. Wisna. 2012. Pelatihan Media Pembelajaran Pendidikan Agama Islam MTS DDI PADANGLAMPEManipulatif. Laporan KKG. Tidak diterbitkan. Singaraja: Undiksha.

Reigeluth, C. M. 1999. Instructioanl-design theories and models: A new paradigm of instructional theory. Volume II. New Jersey: Lawrence Erlbaum Associates, Publishers. Reigeluth, C. M. 1983. Instructioanl-design theories and models: An overview of their current status. Volume I. New Jersey: Lawrence Erlbaum Associates, Publishers.

Smaldino, S.E. , Lowther, D.L. \& Russell, J.D. 2008. Instructional Media and Technology for Learning. $9^{\text {th }}$ Edition. Upper Saddle Rive NJ: Pearson Education, Inc.

Undang-undang RI Nomor 20 tahun 2003 tentang Sisem Pendidikan Nasional. 2003. (Online) tersedia dalam www.hukumonline.com. 